\title{
PENGARUH HUTANG JANGKA PANJANG, HUTANG JANGKA PENDEK, DAN TOTAL EKUITAS TERHADAP PROFITABILITAS PADA PERUSAHAAN SEKTOR INDUSTRI BARANG KONSUMSI DI INDEKS SAHAM SYARIAH (ISSI)
}

\section{EFFECT OF LONG TERM, SHORT TERM, AND TOTAL EQUITY DEBT TO PROFITABILITY IN THE CONSUMPTION GOODS INDUSTRY SECTOR COMPANY IN SHARIAH INDEX} (ISSI)

\author{
Yudha Wijaya'; Qodariah Barkah'2 Muhammadinah ${ }^{3 a}$ \\ 1Universitas Islam Negeri Raden Fatah Palembang, Jl. Prof. K. H. Zainal Abidin Fikri. Kel. Pahlawan. \\ Kec. Kemuning. Kota Palembang. Sumatra Selatan 30126 \\ ${ }^{2}$ Universitas Islam Negeri Raden Fatah Palembang, Jl. Prof. K. H. Zainal Abidin Fikri. Kel. Pahlawan. \\ Kec. Kemuning. Kota Palembang. Sumatra Selatan 30126 \\ ${ }^{3}$ Universitas Islam Negeri Raden Fatah Palembang, Jl. Prof. K. H. Zainal Abidin Fikri. Kel. Pahlawan. \\ Kec. Kemuning. Kota Palembang. Sumatra Selatan 30126 \\ aKorespondensi: Muhammadinah, email: muhammadinah_uin@radenfatah.ac.id
}

\begin{abstract}
This study aims to determine the effect of short-term, long-term debt and total equity on profitability in the Consumer Goods Industry Sector Companies that are registered with ISSI. The study population is all companies in the consumer goods industry sector that are listed on the Indonesia Syariah Stock Index for the 2014-2017 period. The sampling technique in this study used purposive sampling technique. Based on the above criteria, the number that can be sampled is 22 companies. The data analysis technique used in this study uses multiple regression analysis with hypothesis testing using the test and $\mathrm{F}$ test. The results of the study show that short-term debt has no effect on Net Profit Margin in companies listed on the Indonesian Syariah Stock Index in 2014-2017. While long-term debt and total equity affect the Net Profit Margin of companies listed on the 2014-2017 Indonesian Syariah Stock Index.
\end{abstract}

Key words: Short-term Debt, Long-term Debt, Total Equity and Profitability

\section{ABSTRAK}

Penelitian ini bertujuan untuk mengetahui pengaruh hutang jangka pendek, dan jangka panjang serta total ekuitas terhadap profitabilitas pada Perusahaan Sektor Industri Barang Konsumsi yang terdaftar di ISSI. Populasi penelitian yaitu semua perusahaan sektor industri barang konsumsi yang terdaftar di Indeks Saham Syariah Indonesia periode 20142017. Teknik pengambilan sampel pada penelitian ini menggunakan teknik purposive sampling. Berdasarkan kriteria di atas maka jumlah yang dapat dijadikan sampel adalah sebagai 22 perusahaan. Teknik analisis data yang digunakan dalam penelitian ini menggunakan analisis regres berganda dengan pengujian hipotesis menggunakan uji t dan uji F. Hasil penelitian menunjukkan bahwa hutang jangka pendek tidak berpengaruh terhadap Net Profit Margin pada perusahaan yang terdaftar di Indeks Saham Syariah Indonesia tahun 2014-2017. Sedangkan hutang jangka panjang dan total ekuitas berpengaruh terhadap Net Profit Margin pada perusahaan yang terdaftar di Indeks Saham Syariah Indonesia tahun 2014-2017.

Kata kunci: Hutang Jangka Pendek, Hutang Jangka Panjang, Total Equitas dan Profitabilitas 
Yudha Wijaya. 2020. Pengaruh Hutang Jangka Panjang, Hutang Jangka Pendek, dan Total Equitas Terhadap Profitabilitas pada Perusahaan Sektor Industri Barang Konsumsi di Indeks Saham Syariah (ISSI) Jurnal Nisbah 6 (1): 56-62.

\section{PENDAHULUAN}

Suatu perusahaan harus bisa memperhatikan hal yang sangat fundamental yaitu permodalan. Agar dapat produktif dalam menghadapi persaingan, perusahaan harus memberikan perhatian khusus dalam penggunaan modalnya. Penyediaan modal dapat berasal dari sumber internal berupa laba dan eksternal yaitu meliputi hutang jangka panjang, pendek serta modal saham. Hal tersebut bisa membuat perusahaan untuk memenuhi kebutuhan dananya, dengan mengutamakan sumber dana pribadi. Karena adanya pertumbuhan kebutuhan dana yang semakin besar, sehingga untuk memenuhi kebutuhan dana tersebut, perusahaan harus menggunakan modal dari pihak luar berupa hutang.

Pengertian hutang itu sendiri adalah keharusan yang wajib dibayarkan pada saat jatuh tempo. Hutang memiliki risiko yang cukup tinggi hal ini disebabkan karena makin besar tingkat profitabilitas maka akan semakin meningkatkan keuntungan yang diharapkan untuk mengurangi risiko atas hutang (Hartono,2000:254). Sehingga perusahaan bisa menyikapi tindakan untuk melakukan kehati-hatian dalam penggunaan hutang tersebut. Karena sumber dana eksternal tersebut akan menyebabkan perusahaan menghadapi masalah yang berhubungan dengan kemampuan untuk memenuhi kewajiban finansialnya, baik hutang jangka panjang maupun jangka pendek. Sehingga diharapkan pemangku kepentingan dapat mengambil keputusan dalam penggunaan hutang. Jika penggunaan sumber dana asing lebih kecil dari modal sendiri, maka penggunaan modal luar tersebut layak digunakan, namun jika penggunaan modal luar lebih besar dari pada modal sendiri, maka penggunaan modal luar tersebut tidak layak digunakan (Riyanto, 2011:23).

Hutang digunakan untuk mendanai segala aktivitas perusahaan, masalah profitabilitas juga sangatlah penting karena menyangkut kelangsungan hidup suatu perusahaan. Karena hal ini membuat perusahaan untuk terus menghasilkan keuntungan, karena tampa adanya laba pihak perusahan akan sulit untuk menarik modal dari luar. Pihak manajemen perusahan harus berusaha meningkatkan keuntungan demi kelancaran dan kelangsungan suatu perusahaan. Profitabilitas merupakan kemampuan perusahaan dalam memenuhi dan menghasilkan keuntungan melalui semua sumber daya yang ada. Sehingga pihak manajemen perusahaan harus dapat mengambil keputusan dan kebijakan yang tepat dalam hal penggunaan dana yang berasal dari luar perusahaan.

Salah satu perusahan komoditas yang mempunyai peran yang aktif di pasar modal Indonesia adalah sektor industri barang konsumsi. Pada industri ini merupakan investasi yang paling menjanjikan di Indonesia, hal ini dikarenakan barang konsumsi merupakan kebutuhan pokok masyarakat dan cenderung tetap serta berdampak pada kemampuan menghasilkan laba yang optimal.

Berikut data kondisi hutang, ekuitas, dan profitabilitas pada perusahaan sektor industri barang konsumsi ISSI periode tahun 2014-2017 
Tabel 1

Kondisi Hutang Dan Ekuitas Perusahaan Sektor Industri Barang Konsumsi di ISSI Periode 2014-2017

\begin{tabular}{lllll}
\hline \multirow{2}{*}{$\begin{array}{l}\text { Variab } \\
\text { el }\end{array}$} & \multicolumn{4}{c}{ Tahun } \\
\cline { 2 - 5 } & $\mathbf{2 0 1 4}$ & $\mathbf{2 0 1 5}$ & $\mathbf{2 0 1 6}$ & $\mathbf{2 0 1 7}$ \\
\hline H J & 2.221 .1 & 2.477 .1 & 2.309 .2 & 2.694 .4 \\
$\begin{array}{l}\text { Pende } \\
\text { k }\end{array}$ & 81 & 47 & 12 & 61 \\
\hline H J & 1.540 .0 & 1.660 .4 & 1.480 .1 & 1.502 .4 \\
Panjan & 14 & 09 & 86 & 32 \\
g & & & & \\
\hline Total & 4.042 .2 & 4.330 .4 & 4.652 .4 & 4.957 .3 \\
$\begin{array}{l}\text { Ekuita } \\
\text { s }\end{array}$ & 75 & 19 & 63 & 92 \\
\hline Npm & 6,97 & 6,76 & 7,21 & 8,35 \\
\hline
\end{tabular}

Dilihat dari tabel diatas pada periode 2014-2015, ketika terjadi penurunan NPM dari 6,97 menjadi 6,76, variabel hutang jangka pendek mengalami kenaikan dari 2.221.181 menjadi 2.477.147 dan jangka panjang mengalami kenaikan dari 1.540.014 menjadi 1.660.409dan total ekuitas juga mengalami kenaikan dari 4.042 .275 menjadi 4.330.419. Pada periode 20152016, ketika terjadi kenaikan NPM dari 6,76 menjadi 7,21, variabel hutang jangka pendek mengalami penurunan dari 2.477.147 menjadi 2.309.212dan hutang jangka panjang mengalami penurunan dari 1.660.409 menjadi 1.480.186. Berdasarkan data tersebut dapat disimpulkan bahwa keseluruhan data tersebut tidak semua kejadian empiris sesuai dengan teori yang ada.

Hasil penelitian Anita Susanti (2015) menunjukan bahwa hutang jangka pendek berdampak negatif signifikan terhadap net profit margin. Sedangkan pada penelitian Rudi Irawan (2012) menyatakan bahwa variabel hutang jangka pendek berpengaruh signifikan positif terhadap net profit margin. Tetapi pada penelitian Yuniep Mujati Saidah (2008) menyatakan bahwa hutang jangka pendek tidak berpengaruh signifikan terhadap net profit margin.

Hasil penelitian Setiana (2012) hasil penelitian menunjukkan bahwa hutang jangka panjang berpengaruh negatif dan signifikan terhadap net profit margin. Sedangkan pada penelitian Rudi Irawan (2012) menyatakan bahwa variabel hutang jangka panjang tidak berpengaruh signifikan terhadap net profit margin.

Hasil penelitian Anita Susanti (2015) menunjukkan bahwa total ekuitas berpengaruh negatif dan signifikan terhadap net profit margin. Sedangkan penelitian yang dilakukan oleh Graha cendikia (2012) menyatakan bahwa total ekuitas tidak berpengaruh terhadap net profit margin.

Penelitian ini berusaha untuk mengembangkan penelitian terdahulu mengenai pengaruh hutang dan ekuitas terhadap profitabilitas. Terdapatnya perbedaan hasil pada penelitian terdahulu mendorong peneliti untuk melakukan penelitian ini. Sampel yang digunakan peneliti adalah Perusahaan sekor industri barang konsumsi yang terdaftar di ISSI periode tahun 2014-2017.

\section{MATERI DAN METODE}

Modal merupakan seluruh aset atau kekayaan yang dimiliki oleh perusahaan yang terdiri atas kekayaan yang disetor atau yang berasal dari luar perusahaan dan kekayaan itu hasil aktivitas usaha itu sendiri (Munawir, 2007:19). Dalam memenuhi kebutuhan modal perlu adanya kegiatan untuk membiayai operasional yang didapat dari sumber pembiayaan yang berasal dari eksternal dan internal. Modal tersebut merupakan hutang yang harus dibayarkan kembali (Riyanto,2011:209). Jika perusahaan tidak mendapatkan profit yang baik, maka akan berat bagi pihak perusahaan untuk mendapatkan permodalan dari pihak luar.

\section{a. Gross profit margin}

Gross profit margin atau laba kotor menunjukan laba yang relatif terhadap perusahaan, dengan cara penjualan bersih dikurangi harga pokok penjualan. Rasio ini merupakan cara 
untuk menetapkan harga pokok penjualan (Kasmir, 2013:199)

Rumus Gross profit margin sebagai berikut:

Gross Profit Margin

\section{b. Net Profit Margin}

$$
=\frac{\text { Gross profit }}{\text { Sales }} \times 100 \%
$$

Net profit margin adalah ukuran keuntungan dengan membandingkan antara laba setelah bunga dan pajak dibandingkan dengan penjualan. Untuk mengukur kapabilitas suatu perusahaan dalam menghasilkan keuntungan dengan menggunakan penjualan yang dicapai perusahaan. Semakin tinggi rasio maka akan menunjukan bahwa perusahaan efektif dalam melaksanakan kegiatannya (Kasmir, 2013:200).

Rumus Net Profit Margin sebagai berikut:

$$
\begin{aligned}
& \text { Net Profit Margin } \\
& =\frac{\text { Earning After Interest and Tax }}{\text { Sales }} \\
& \times 100 \%
\end{aligned}
$$

\section{c. Return On Investment (ROI)}

Return on investment merupakan rasio yang menunjukan hasil (return) atas jumlah aktiva yang digunakan dalam perusahaan. Rasio ini menunjukan sejauh mana investasi yang telah diperoleh mampu menghasilkan pengembalian profit dengan yang diharapkan (Kasmir, 2013:201).

Rumus Return on assets sebagai berikut:

$$
\begin{aligned}
& \text { Return on assets } \\
& =\frac{\text { Earning After Interest and Tax }}{\text { Total assets }} \\
& \times 100 \%
\end{aligned}
$$

\section{d. Return on equity (ROE)}

ROE yaitu menggambarkan perusahaan untuk bisa memperoleh keuntungan setelah pajak. Rasio ini penting bagi para pihak investor untuk mengetahui efisien dan efektivitas dalam pengelolaan modal yang dilakukan oleh pihak manajemen. (Kasmir, 2013:202). Rumus Return on Equity sebagai berikut:

$$
\begin{aligned}
& \text { Return on equity } \\
& =\frac{\text { Earning After Interest and Tax }}{\text { Total equity }} \\
& \times 100 \%
\end{aligned}
$$

Populasi dalam penelitian ini adalah semua perusahaan sektor industri barang konsumsi yang terdaftar di Indeks Saham Syariah Indonesia periode 2014-2017. Teknik pengambilan sampel pada penelitian ini menggunakan teknik purposive sampling dengan tujuan mendapatkan sampel yang sesuai dengan kriteria yang ditentukan. Teknik analisis data yang digunakan dalam penelitian ini menggunakan analisis regresi berganda dengan pengujian hipotesis menggunakan uji t dan uji F.

\section{HASIL DAN PEMBAHASAN}

\section{Analisis Deskriptif Variabel Not Profit Margin}

Tabel statistik deskriptif diatas jumlah data yang digunakan dalam penelitian ini berjumlah 88 observasi. Sehingga dapat dijelaskan hasil sebagai berikut :

1. Net Profit Margin menunjukan nilai minimumnya 0,24 dan maksimumnya 21,02 dengan standar deviasi 5,47880, sedangkan meannya atau rata-ratanya menunjukan 7,0899 artinya dari semua perusahaan yang dijadikan sampel rata-rata Net Profit Marginnya adalah 7,0899 . Hasil ini menunjukan bahwa sampel perusahaan dalam penelitian ini telah berhasil menghasilkan laba maksimal atau dapat dikategorikan cukup baik.

2. Hutang Jangka Pendek menunjukan nilai minimumnya 8.227 dan maksimumnya 25.107.538 dengan standar deviasi 5.058.475,69155, 
sedangkan meannya atau rata-ratanya menunjukan 2.425.500,9545 artinya dari semua perusahaan yang dijadikan sampel rata-rata Hutang Jangka Pendeknya adalah 2.425.500,9545.

3. Hutang Jangka Panjang menunjukan nilai minimumnya 5.309 dan maksimumnya 23.602.395 dengan standar deviasi 4.463.389,53630, sedangkan meannya atau rata-ratanya menunjukan 1.545.760,7500 artinya dari semua perusahaan yang dijadikan sampel rata-rata Hutang Jangka Panjangnya adalah 1.545.760,7500.

4. Total Equitas menunjukan nilai minimumnya 78.680 dan maksimumnya 45.964.261 dengan standar deviasi 9.564.597,97421, sedangkan meannya atau rata-ratanya menunjukan 4.495.637,7045 artinya dari semua perusahaan yang dijadikan sampel rata-rata Hutang Jangka Pendeknya adalah 4.495.637,7045.

\section{Uji Asumsi Klasik}

Sebelum dilakukan pengujian regresi linier berganda terhadap hipotesis penelitian, maka terlebih dahulu perlu dilakukan suatu pengujian untuk mengetahui ada atau tidaknya pelanggaran terhadap hipotesis. Hasil pengujian hipotesis yang baik adalah pengujian yang tidak melanggar asumsi klasik yang mendasari model regresi linier berganda. Asumsi-asumsi klasik dalam penelitian ini meliputi uji normalitas, uji multikolinearitas, uji autokorelasi, uji heterokedastisitas dan uji linieritas.

\section{Uji Normalitas}

Berdasarkan Tabel 3 diperoleh nilai KSZ sebesar 1,234 dan Asymp. Sig. sebesar 0,091 lebih besar 0,05 maka dapat disimpulkan data berdistribusi normal.

\section{Uji Multikolinearitas}

Berdasarkan Tabel 4 diketahui bahwa nilai tolerance semua variabel independen $>0,10$. Nilai VIF semua variabel independen $<10,00$. Berdasarkan kriteria dalam pengambilan keputusan dapat disimpulkan bahwa tidak terjadi multikolinieritas.

\section{Uji Autokorelasi}

Berdasarkan Tabel 5 diketahui nilai DW 0,879. Berdasarkan kriteria pengambilan keputusan bahwa nilai DW di antara -2 sampai +2 berarti tidak ada autokorelasi.

Hasil tampilan output menunjukkan nilai $\mathrm{R}^{2}$ sebesar 0,293 dengan jumlah $\mathrm{n}$ observasi 88 , maka besarnya nilai $c^{2}$ hitung $=88 \times 0,293=$ 25,784 . Nilai ini dibandingkan dengan $c^{2}$ tabel dengan $\mathrm{df}=(\mathrm{n}-\mathrm{k})=88-8=80$ dan tingkat signifikansi 0,05 didapat nilai $\mathrm{c}^{2}$ tabel 101,87947. Oleh karena nilai $c^{2}$ hitung lebih kecil dari $c^{2}$ tabel, maka dapat disimpulkan bahwa hipotesis alternative adanya heterokedastisitas dalam model ditolak.

\section{Uji Linieritas}

Salah satu cara untuk menentukan linearitas adalah dengan uji Lagrange Multiplier dengan membandingkan nilai $\mathrm{c}^{2}$ hitung dengan $\mathrm{c}^{2}$ tabel. Jika nilai $\mathrm{c}^{2}$ hitung $>\quad c^{2}$ tabel, maka hipotesis yang menyatakan model linear ditolak.

Hasil tampilan output menunjukkan nilai $\mathrm{R}^{2}$ sebesar 0,003 dengan jumlah $\mathrm{n}$ observasi 88 , maka besarnya nilai $\mathrm{c}^{2}$ hitung $=88 \times 0,003=0,264$. Nilai ini dibandingkan dengan $\mathrm{c}^{2}$ tabel dengan $\mathrm{df}=$ $(\mathrm{n}-\mathrm{k})=88-4=84$ dan tingkat signifikansi 0,05 didapat nilai $c^{2}$ tabel 106,39484 . Oleh karena nilai $\mathrm{c}^{2}$ hitung lebih kecil dari $\mathrm{c}^{2}$ tabel, maka dapat disimpulkan bahwa model yang benar adalah model linear.

\section{Uji Hipotesis}

\section{Uji Simultan (Uji F)}

Secara simultan pengujian hipotesis dilakukan dengan uji F. Uji statistik F pada dasarnya menunjukkan apakah variable independen Hutang Jangka Pendek, Hutang Jangka Panjang dan Total Equitas yang dimasukkan dalam model mempunyai pengaruh secara bersama-sama terhadap variable dependen yaitu Net Profit Margin. Berikut tabel hasil uji simultan (uji F) menggunakan SPSS: 
Hasil tampilan output menunjukkan nilai $F$ hitung yaitu 18,066 . Nilai ini dibandingkan dengan $\mathrm{F}$ tabel dengan $\mathrm{df} 1=\mathrm{k}-1=4-1=3$ dan df $2=\mathrm{n}-\mathrm{k}=$ $88-4=84$, sehingga didapat nilai $\mathrm{F}$ tabel 2,71. Karena nilai $\mathrm{F}$ hitung $>$ Ftabel yaitu 18,066 > 2,71 dengan nilai signifikasi $0,000<0,05$ jadi dapat disimpulkan bahwa pada penelitian ini ketiga variabel yaitu Hutang Jangka Pendek, Hutang Jangka Panjang dan Total Equitas memiliki pengaruhi secara simultan terhadap Net Profit Margin.

\section{Uji Koefisien Determinasi (R2)}

Uji koefisien determinasi (R2) dalam persamaan regresi berganda digunakan untuk menunjukan seberapa besar variabel independen dapat menjelaskan variasi variabel dependen. Berikut tabel hasil pengujian koefisien determinasi (R2) menggunakan SPSS:

Berdasarkan tabel diatas dapat dilihat bahwa nilai $\mathrm{R}$ square adalah 0,370 . Artinya variabel $\mathrm{Y}$ dapat dijelaskan oleh variabel $X$ sebesar 37\%. Sisanya $63 \%$ dijelaskan oleh variabel lain yang tidak dibahas dalam penelitian ini.

\section{Uji Parsial (Uji t)}

Secara parsial, pengujian hipotesis dilakukan dengan uji t. Uji statistik $\mathrm{t}$ pada dasarnya menunjukkan seberapa jauh pengaruh satu variable independen Hutang Jangka Pendek, Hutang Jangka Panjang dan Total Equitas secara individual dalam menerangkan variable dependen yaitu Net Profit Margin. Berikut tabel hasil uji parsial (uji t) menggunakan SPSS.

Berdasarkan hasil pengolahan data menunjukan bahwa pada penelitian ini variabel Hutang Jangka Pendek tidak memiliki pengaruh terhadap Net Profit Margin karena nilai -t hitung > - $\mathrm{t}$ tabel yaitu $-1,851>-1,98861$ dan dianggap tidak signifikan dengan nilai signifikasi 0,068 >0,05.

Pada penelitian ini variabel Hutang Jangka Panjang memiliki pengaruh terhadap Net Profit Margin karena nilai -t hitung $<-$ t tabel yaitu $-2,778<-1,98861$ dan dianggap signifikan dengan nilai signifikasi 0,007 $<0,05$. Artinya secara parsial terdapat pengaruh negatif signifikan antara Hutang Jangka Panjang terhadap Net Profit Margin.

Pada penelitian ini variabel Total Equitas memiliki pengaruh terhadap Net Profit Margin karena nilai t hitung $>\mathrm{t}$ tabel yaitu $6,270>1,98861$ dan dianggap signifikan dengan nilai signifikasi $0,000<$ 0,05 . Artinya secara parsial terdapat pengaruh positif signifikan antara Total Equitas terhadap Net Profit Margin.

\section{KESIMPULAN DAN IMPLIKASI}

Berdasarkan pengolahan dan pembahasan yang telah dilakukan oleh penulis tentang pengaruh Hutang Jangka Pendek, Hutang Jangka Panjang dan Total Equitas terhadap Net Profit Margin pada perusahaan yang terdaftar di Indeks Saham Syariah Indonesia tahun 20142017 maka dapat disimpulkan:

1. Bedasarkan hasil uji simultan terdapat pengaruh yang signifikan diantara variabel Hutang Jangka Pendek, Hutang Jangka Panjang dan Total Equitas terhadap Net Profit Margin pada perusahaan yang terdaftar di Indeks Saham Syariah Indonesia tahun 2014-2017.

2. Berdasarkan hasil uji parsial (uji t) variabel Hutang Jangka Pendek tidak berpengaruh terhadap Net Profit Margin pada perusahaan yang terdaftar di Indeks Saham Syariah Indonesia tahun 2014-2017.

3. Berdasarkan hasil uji parsial (uji t) variabel Hutang Jangka Panjang berpengaruh secara negatif signifikan terhadap Net Profit Margin pada perusahaan yang terdaftar di Indeks 
Saham Syariah Indonesia tahun 20142017.

4. Berdasarkan hasil uji parsial (uji t) variabel Total Equitas berpengaruh secara positif signifikan terhadap Net Profit Margin pada perusahaan yang terdaftar di Indeks Saham Syariah Indonesia tahun 2014-2017.

\section{DAFTAR PUSTAKA}

Arikunto, Suharsimi, Prosedur Penelitian Suatu Pendekatan Praktik, Jakarta: Rhineka Cipta, 2013.

Baridwan, Intermediate Accounting, Yogyakarta: BPFE, 2000.

Brigham dan Houston, Dasar-dasar Manajemen Keuangan, Jakarta: Salemba Empat, 2006.

Fahmi, Irham, Manajemen Keuangan, Bandung: Alfabeta, 2014.

Ghozali, Imam, Aplikasi Analisis Multivariate dengan Program (edisi ketujuh), Semarang: Badan Penerbit Universitas Diponegoro, 2013.

Ghozali, Imam, Aplikasi Analisis Multivariate dengan program IBM SPSS 19, Edisi 5, Semarang: Universitas Diponegoro, 2011.

Harahap, Analisis Kritis Atas Laporan Keuangan, Jakarta: Raja Grafindo Persada, 2005

Hartono, Teori Portofolio dan Analisis Investasi, Yogyakarta: BPFE, 2000.

Horne, Van dan Wachowicz, Prinsipprinsip Manajemen Keuangan, Jakarta: Salemba Empat, 2012.

Ikatan Akuntansi Indonesia, Standar Akuntansi Keuangan, Jakarta: Salemba Empat, 2002

Kasmir, Analisis Laporan Keuangan, Jakarta: Raja Grafindo Persada, 2013.

Martono, Nanang, Metode Penelitian Kuantitatif, Analisis Dan Analisis Data Sekunder, Depok: PT. Raja Grafindo Persada, 2011.

Munawir, Analisis Laporan Keuangan, Yogyakarta: Liberty, 2007.
Riyanto, Dasar-dasar Pembelanjaan Perusahaan, Yogyakarta: BPFE, 2011.

Rudianto, Pengantar Akuntansi, Jakarta: Erlangga, 2008.

Santoso, Singgih, Buku Latihan SPSS, Jakarta: PT. Elex Media Komputindo, 2000.

Sudana, Manajemen Keuangan Perusahaan Teori \& Praktik, Jakarta: Erlangga, 2011.

Sugiyono, Metode Penelitian kuantitatif, Kualitatif, dan R\&D, Bandung: Alfabeta, 2012.

Sumarni, Dasar-dasar Ekonomi Perusahaan, Yogyakarta: Liberty, 2006.

Sutrisno, Manajemen Keuangan, Yogyakarta: Ekonisia, 2003.

Turmudi, dan Sri Harini, Metode Statistika, Pendekatan Teoritis Dan Aplikatif, Malang: UIN Malang PRESS, 2007. 